\title{
THE EFFECT OF PROMOTION AND PRICE ON PURCHASE DECISIONS
}

\author{
Ade Yusuf ${ }^{\star 1}$, Denok Sunarsi ${ }^{2}$ \\ Universitas Pamulang, Indonesia \\ dosen02604@unpam.ac.id ${ }^{* 1}$, denoksunarsi@unpam.ac.id ${ }^{2}$
}

\begin{abstract}
The progress of a business is closely related to business management, while the rate of growth of a company is influenced by many things such as product development, sales concepts, and marketing concepts, therefore the sales concept and marketing concept are inseparable from promotional activities. Promotional activities are activities to promote goods directly to attract prospective buyers to the products being promoted Along with the advancing development of the era of the need for fashion has become a separate requirement for the community at large. And for products sold by PT. This study aims to determine the effect of promotion and price on purchasing decisions at PT. Total Creation. The method used was explanatory research with a sample of 96 consumers. The analysis technique uses statistical analysis with regression testing, correlation, determination, and hypothesis testing. The results of this study have a significant effect on the promotion of purchasing decisions by $41.1 \%$, hypothesis testing obtained significance $0,000<0.05$. Price significantly influence the purchase decision of $42.4 \%$, the hypothesis test obtained significance of $0,000<0.05$. Promotion and price simultaneously have a significant effect on purchasing decisions of $51.9 \%$, hypothesis testing obtained significance of $0,000<0.05$.
\end{abstract}

Keywords: Promotion, Price, Purchase Decision

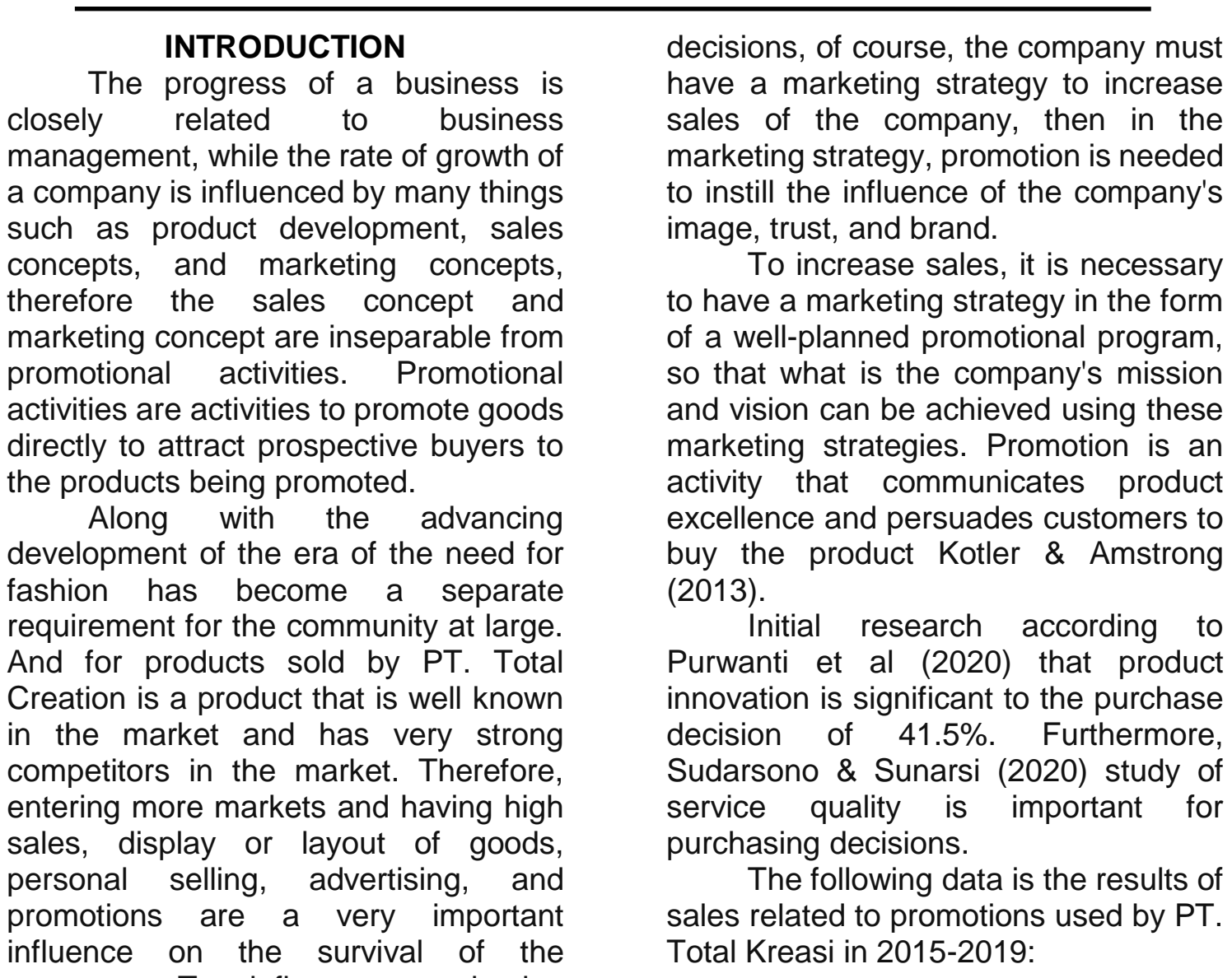

company. To influence purchasing 
Table 1. Sales Data for PT. Total Creation at Matahari Department Store Ciputat

\begin{tabular}{rlll}
\hline \multicolumn{1}{c}{ Period } & \multicolumn{1}{c}{ Sales } & \multicolumn{1}{c}{ Promotion } & \multicolumn{1}{c}{ Target } \\
\hline 2019 & $4998 \mathrm{pcs}$ & Disc 20\%-30\%, BIGl & 5.550 pcs \\
2018 & $4.756 \mathrm{pcs}$ & Disc 20\%-30\% & $5.130 \mathrm{pcs}$ \\
2017 & $4.845 \mathrm{pcs}$ & Disc 20\%-30\%,20+20\% & $5.200 \mathrm{pcs}$ \\
2016 & $3.243 \mathrm{pcs}$ & Disc 20\%,B1 20\% B2 30\% & $3.560 \mathrm{pcs}$ \\
2015 & $2.3222 \mathrm{pcs}$ & Disc 20\%-30\% & $2.310 \mathrm{pcs}$ \\
\hline
\end{tabular}

Source: PT. Total Kreasi (2015-2019)

Based on these data, the promotion used by PT. Total Creation is still ineffective because the sales results are still experiencing fluctuations wherein 2018 this has decreased due to promotions conducted by PT. Total Creative is less competitive compared to the competition and the lack of consumer response to promotional activities by PT. Even Total Creation has given discounts either directly or using online media while the promotion is done in the form of advertising, this type of promotion is carried out by online media, personal selling which aims to sell goods directly to buyers, sales promotion forms of promotion carried out to stimulate buyers such as giving examples of goods or samples and cashback or cashback and discounted prices.

Table 2. List of Promotions between Competitors

\begin{tabular}{cc}
\hline Brand & Promotion \\
\hline Expand, Exit Dan Exit Kids & Disc $20 \%, 30 \% \&$ BIGI \\
Dust Jeans & Disc $20+20 \% \& 70 \%$ \\
Dual Casual & Disc $20+20 \% \& 70 \%$ \\
Rodeo & Special Price \& $50 \%$ \\
Triset & Disc $30 \% \& 50 \%$ \\
\hline
\end{tabular}

Source: Matahari Department Store Ciputat (2015-2019)

It can be seen from the table above that the promotions of competitors in Matahari Department Store Ciputat vary greatly so that Ciputat consumers are less responsive to the products offered by the Expand, Exit and Exit Kids brands. Where the company must pay attention to promotions carried out by competitors in the Matahari Department Store Ciputat to improve consumer response.

Given the importance of promotion to captivate the hearts of consumers who certainly have a goal to make a profit to increase sales for the company, it is hoped that effective promotion will be able to increase sales. In addition to the promotional media that is used less effectively, other factors cause purchasing decisions to decrease, this is also caused by the price factor where the price is the amount of money that customers must pay for the product, According to Kotler (2012) while according to Kotler \& Amstrong (2013), the amount of money that consumers exchange for the benefits of owning or using the product or service. So the price offered varies depending on the brand of each product. The following table lists prices and brands Expand, Exit and Exit Kids Department Store Ciputat. 
Almana : Jurnal Manajemen dan Bisnis Vol. 4 No. 2/ Agustus 2020

ISSN 2579-4892 print/ ISSN 2655-8327 online

Table 3. Price List of Each Brand

\begin{tabular}{llll}
\hline \multicolumn{1}{c}{ Brand } & \multicolumn{1}{c}{ T-Shirt } & \multicolumn{1}{c}{$\begin{array}{c}\text { Price } \\
\text { Blouse }\end{array}$} \\
& Rp. 339.900 & Rp. 379.900 & Jeans \\
\hline Expand & Rp. 359.900 & RP. 399.900 & Rp. 429.990 \\
Exit Dewasa & Rp. 299.900 & Rp. 339.900 & Rp. 399.900 \\
& Rp.319.900 & Rp.379.900 & Rp.419.900 \\
Exid Kids & Rp. 199.900 & Rp. 239.900 & Rp.299.900 \\
& Rp. 219.900 & Rp. 259.900 & Rp.339.900 \\
\hline
\end{tabular}

Source: PT. Total Kreasi Tbk (2015-2019)

Based on the table above, the price list offered by PT. These total Kreasi have different cause's consumers to be more sensitive to the prices offered by PT. Total Creation, so that consumers turn to competitors at lower prices. Besides the price offered is also relatively expensive so that the decision level is still not reached optimally.

The purchasing decision is a purchase decision process consisting of five stages carried out by a consumer before arriving at a purchase decision and subsequently post-purchase, Kotler (2012) one of which is evaluating the price and promotion factors used by the company. Based on this background, the authors are interested in researching the title Effect of Promotion and Price on Purchasing Decisions at PT. Total Product Creation from Expand, Exit, and Exit Kids (Case Study of Matahari Department Store Ciputat Consumers).

\section{METHODS}

The population in this study amounted to 96 consumers PT. Total Creation. The sampling technique in this study is saturated sampling, where all members of the population are sampled. Thus the sample in this study amounted to 96 consumers. The type of research used is associative, where the aim is to find out the search for interconnection. In analyzing the data used the instrument test, classical assumption test, regression, coefficient of determination, and hypothesis testing.

\section{RESULTS AND DISCUSSION Descriptive Analysis}

This test used to determine the minimum and maximum scores, mean scores, and standard deviations of each variable. The results are as follows:

Table 4. Results of Descriptive Statistics Analysis

\begin{tabular}{lcccr}
\hline & \multicolumn{4}{c}{$\begin{array}{c}\text { Descriptive Statistics } \\
\text { N }\end{array}$} \\
& 96 & 32 & 4838.42 & 3.890 \\
Promotion (X1) & 96 & 30 & 4538.45 & 3.610 \\
Price (X2) & 96 & 32 & 4639.24 & 3.541 \\
Purchase decision (Y) & 96 & 32 & & \\
Valid N (listwise) & 96 & & & \\
\hline
\end{tabular}

Promotion obtained a minimum variance of 32 and a maximum variance of 48 with a mean score of 3.84 with a standard deviation of 3.890 . Prices obtained a minimum variance of 30 and a maximum variance of 45 with a mean score of 3.84 with a standard deviation of 3.610. The purchase decision 
obtained a minimum variance of 32 and a maximum variance of 46 with a mean score of 3.92 with a standard deviation of 3.541 .

\section{Verification Analysis}

This analysis is intended to determine the effect of independent variables on the dependent variable. The test results are as follows:

\section{Multiple Linear Regression Analysis}

This regression test is intended to determine changes in the dependent variable if the independent variable changes. The test results are as follows:

Table 5. Results of Multiple Linear Regression Testing

\begin{tabular}{|c|c|c|c|c|}
\hline \multirow{3}{*}{ Model } & \multicolumn{3}{|c|}{ Coefficients $^{a}$} & \multirow{3}{*}{$\mathrm{Siq}$} \\
\hline & \multicolumn{2}{|c|}{$\begin{array}{l}\text { Unstandardized } \\
\text { Coefficients }\end{array}$} & \multirow{2}{*}{$\begin{array}{c}\text { Standardized } \\
\text { Coefficients } \\
\text { Beta }\end{array}$} & \\
\hline & B & Std. Error & & \\
\hline 1(Constal & 10.029 & 2.933 & & 419.00 \\
\hline $\begin{array}{l}\text { Promotion } \\
\text { (X1) }\end{array}$ & .354 & .083 & .3894 & 283.0 \\
\hline Price (X2) & .406 & .089 & .4144. & 556.00 \\
\hline
\end{tabular}

Source: Processed Data (2020)

Based on the test results in the above table, the regression equation $\mathrm{Y}=$ $10.029+0.354 \mathrm{X} 1+0.406 \mathrm{X} 2$ is obtained. From the equation explained as follows:

A constant of 10,029 means that if there is no promotion and price, then there is a purchase decision value of 10,029 points. The promotion regression coefficient of 0.354 , this number is positive, meaning that every time there is an increase in the promotion of 0.354 , the purchasing decision will also increase by 0.354 points. The price regression coefficient of 0.406 , this number is positive, meaning that every time there is an increase in the price of 0.406 , the purchasing decision will also increase by 0.406 points.

\section{Correlation Coefficient Analysis}

Correlation coefficient analysis is intended to determine the degree of relationship strength of the independent variables on the dependent variable either partially or simultaneously. The test results are as follows:

Table 6. NTest Results for Promotion Correlation Coefficient on Purchasing Decisions

\begin{tabular}{|c|c|c|c|}
\hline \multicolumn{4}{|c|}{ Correlations } \\
\hline & & Promotion (X1) & Purchase decision $(\mathrm{Y})$ \\
\hline Promotion (X1) & $\begin{array}{l}\text { Pearson Correlation } \\
\text { Sig. (2-tailed) }\end{array}$ & 1 & $\begin{array}{l}.641^{* *} \\
.000\end{array}$ \\
\hline Purchase decision $(\mathrm{Y})$ & $\begin{array}{l}\text { Pearson Correlation } \\
\text { Sig. (2-tailed) }\end{array}$ & $\begin{array}{l}.641^{\star *} \\
.000\end{array}$ & 1 \\
\hline **. C & $\begin{array}{r}\text { elation is significant at } \\
\text { b. Listwise }\end{array}$ & $\begin{array}{l}0.01 \text { level (2-ta } \\
96\end{array}$ & \\
\hline
\end{tabular}

Based on the test results obtained by a correlation value of 0.641 means that promotion has a strong relationship with purchasing decisions. 
Table 7. Test Results for Price Correlation Coefficient on Purchasing Decisions

\begin{tabular}{llrr}
\hline & \multicolumn{1}{c}{ Correlations $^{\mathbf{b}}$} & Price $(\mathrm{X} 2)$ & Purchase decision (Y) \\
\hline Price $(\mathrm{X} 2)$ & Pearson Correlation & 1 & $.651^{* *}$ \\
& Sig. (2-tailed) & .000 \\
Purchase decision $(\mathrm{Y})$ & Pearson Correlation & $.651^{* *}$ & 1 \\
& Sig. (2-tailed) & .000 & \\
**. Correlation is significant at the 0.01 level (2-tailed). & & \\
b. Listwise N=96 & & & \\
\hline
\end{tabular}

Source: Processed Data (2020)

Based on the test results obtained by the correlation value of 0.651 means that prices have a strong relationship with purchasing decisions.

Table 8. Simultaneous Correlation Results of Promotional and Price Correlation Tests against Purchasing Decisions

\begin{tabular}{ccccc}
\hline Model & $\mathrm{R}$ & \multicolumn{2}{c}{ Model Summary } \\
$\mathrm{R}$ Square & Adjusted R Square & $\begin{array}{c}\text { Std. Error of the } \\
\text { Estimate }\end{array}$ \\
\hline 1 & & $.720^{\mathrm{a}}$ & $\begin{array}{c}.519 \\
\text { a. Predictors: (Constant), Price (X2), Promotion (X1) }\end{array}$ & 2.483 \\
\hline
\end{tabular}

Source: Processed Data (2020)

Based on the test results obtained a correlation value of 0.720 means that simultaneous promotion and price have a strong relationship to purchasing decisions.

\section{Analysis of the Coefficient of Determination}

Analysis of the coefficient of determination is intended to determine the percentage of influence of the independent variable on the dependent variable either partially or simultaneously. The test results are as follows:

Table 9. Test Results for Promotion Determination Coefficient on Purchasing Decisions

\begin{tabular}{ccccc}
\hline \multirow{2}{*}{ Model } & $\mathrm{R}$ & \multicolumn{2}{c}{ Model Summary } \\
$\mathrm{R}$ Square & Adjusted R Square & $\begin{array}{c}\text { Std. Error of the } \\
\text { Estimate }\end{array}$ \\
\hline 1 & $.641^{\mathrm{a}}$ & $\begin{array}{c}.411 \\
\text { a. Predictors: (Constant), Promotion }(\mathrm{X} 1)\end{array}$ & 2.731 \\
\hline \multicolumn{4}{c}{ Source: Processed Data (2020) }
\end{tabular}

Based on the test results obtained a determination value of 0.411 means that promotion has an influence contribution of $41.1 \%$ to the purchase decision. 
Table 10. Test Results for the Price Determination Coefficient on Purchasing Decisions

\begin{tabular}{|c|c|c|c|c|}
\hline \multicolumn{5}{|c|}{ Model Summary } \\
\hline Model & $\mathrm{R}$ & R Square & Adjusted R Square & $\begin{array}{c}\text { Std. Error of the } \\
\text { Estimate }\end{array}$ \\
\hline 1 & $.651^{\mathrm{a}}$ & .424 & .418 & 2.702 \\
\hline \multicolumn{5}{|c|}{ a. Predictors: (Constant), Price (X2) } \\
\hline
\end{tabular}

Based on the test results obtained a determination value of 0.424 means that the price has an influence

Table 11. Test Results for Promotion Determination Coefficient and Purchasing Decisions

\begin{tabular}{|c|c|c|c|c|}
\hline \multicolumn{5}{|c|}{ Model Summary } \\
\hline Model & $\mathrm{R}$ & R Square & Adjusted R Square & $\begin{array}{l}\text { Std. Error of the } \\
\text { Estimate }\end{array}$ \\
\hline 1 & $\begin{array}{l}.720^{\mathrm{a}} \\
\text { a. Pred }\end{array}$ & $\begin{array}{c}.519 \\
\text { nstant), Pri }\end{array}$ & $\begin{array}{c}509 \\
\text { X2), Promotion (X1) }\end{array}$ & 2.483 \\
\hline
\end{tabular}

Based on the test results obtained a determination value of 0.519 means that promotion and price simultaneously have an influence contribution of $51.9 \%$ to the purchase decision, while the remaining $48.1 \%$ is influenced by other factors contribution of $42.4 \%$ to the purchase decision.

\section{Table 12. Results of the Promotional Hypothesis Test against Purchasing Decisions}

\begin{tabular}{|c|c|c|c|c|c|c|}
\hline \multicolumn{7}{|c|}{ Coefficients $^{a}$} \\
\hline & \multirow[t]{2}{*}{ Model } & $\begin{array}{r}\text { Unst } \\
\text { Co }\end{array}$ & $\begin{array}{l}\text { ardized } \\
\text { ients }\end{array}$ & \multirow{2}{*}{$\begin{array}{c}\text { Standardized } \\
\text { Coefficients } \\
\text { Beta }\end{array}$} & \multirow[t]{2}{*}{$\mathrm{t}$} & \multirow[t]{2}{*}{ Sig. } \\
\hline & & B & Std. Error & & & \\
\hline \multirow[t]{3}{*}{1} & (Constant) & 16.804 & 2.782 & & 6.041 & .000 \\
\hline & Promotion (X1) & .584 & .072 & .641 & 8.106 & .000 \\
\hline & & a. Depen & Variable: & se decision $(Y)$ & & \\
\hline
\end{tabular}

Based on the test results in the above table, the value of $t$ count $>t$ table or $(8,106>1,661)$ is obtained, thus the

\section{Hypothesis testing}

Hypothesis testing with a t-test is used to find out which partial hypotheses are accepted.

First Hypothesis: There is a significant influence between promotions on purchasing decisions.

Table 13. Results of Price Hypothesis Tests on Purchasing Decisions

\begin{tabular}{llccccc}
\hline & & \multicolumn{6}{c}{ Coefficients $^{\mathbf{a}}$} \\
& Model & \multicolumn{2}{c}{ Unstandardized Coefficients } & Standardized Coefficients & t & Sig. \\
& & $\mathrm{B}$ & Std. Error & Beta & & \\
\hline 1 & (Constant) & 14.678 & 2.966 & & 4.949 & .000 \\
& Price (X2) & .639 & .077 & .651 & 8.317 & .000 \\
& & a. Dependent Variable: Purchase decision (Y) & & \\
\hline
\end{tabular}

Source: Processed Data (2020) 
Based on the test results in the above table, the value of $t$ count $>t$ table or (8.317> 1.661) is obtained, thus the second hypothesis is proposed that there is a significant influence on the price of purchasing decisions accepted.
Hypothesis testing with the $F$ test is used to find out which simultaneous hypotheses are accepted. The third hypothesis there is a significant influence between promotion and price on purchasing decisions.

Table 14. Results of Promotional Hypothesis Tests and Prices against Purchasing Decisions

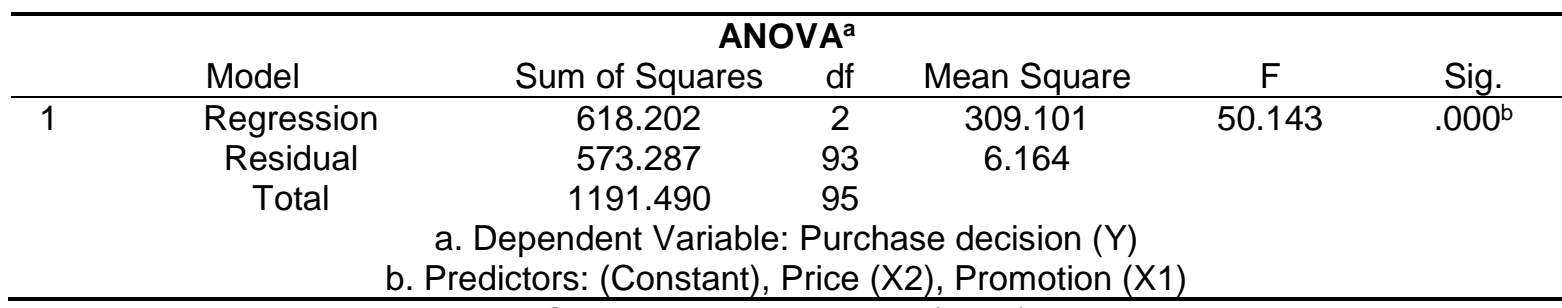

Source: Processed Data (2020)

Based on the test results in the above table, the calculated $\mathrm{F}$ values $\mathrm{F}$ table or $(50.143>2,700)$, thus the third hypothesis proposed that there is a significant influence between promotion and price on the purchase decision is accepted.

\section{Effect of Promotion on purchasing decisions}

The promotion has a significant effect on purchasing decisions with a correlation of 0.641 or has a strong relationship with a contribution of $41.1 \%$. Hypothesis testing obtained $t$ value $>t$ table or $(8,106>1,661)$. Thus the first hypothesis proposed that there is a significant influence between promotion and purchase decision is accepted.

\section{Effect of Prices on Purchasing Decisions}

Price has a significant effect on purchasing decisions with a correlation of 0.651 or has a strong relationship with a contribution of $42.4 \%$. Hypothesis testing obtained $\mathrm{t}$ value $>\mathrm{t}$ table or (8.317> 1.661). Thus the second hypothesis is proposed that there is a significant effect between the prices on the purchase decision received.

\section{The Effect of Promotion and Price on Purchasing Decisions \\ Promotion and price have a} significant effect on purchasing decisions with the obtained regression equation $Y=10.029+0.354 \mathrm{X} 1+$ $0.406 \times 2$, the correlation value of 0.720 , or have a strong relationship with the contribution of influence of $51.9 \%$ while the remaining $48.1 \%$ is influenced by other factors. Hypothesis testing obtained values $\mathrm{F}$ count> $\mathrm{F}$ table or (50.143> 2.700). Thus the third hypothesis proposed that there is a significant effect between promotion and price on purchasing decisions is accepted.

\section{CONCLUSION}

The promotion has a significant influence on purchasing decisions with the effect of contributions. Hypothesis testing is obtained $t_{\text {count }}>t_{\text {table. }}$. Price has a significant effect on purchasing decisions with the effect of contributions. Hypothesis testing is obtained $t_{\text {count }}>t_{\text {table }}$ or promotion and price have a significant effect on purchasing decisions.

\section{REFERENCES}

Kotler, Philip \& Amstrong, Gary. (2013). Principle of Marketing. New Jersey: Prentice-Hall. 
Kotler, Philip. (2012). Manajemen Pemasaran di Indonesia: Analisis, Perencanaan, Implementasi dan Pengendalian. Jakarta: Penerbit Salemba. Empat.

Purwanti., Sarwani., Sunarsi. D. (2020) Pengaruh inovasi produk dan brand awareness tehadap keputusan pembelian konsumen pada PT uniliver indonesia. Journal Inovasi, 7(1).

Sudarsono, A \& Sunarsi, D. (2020). Pengaruh Kualitas Pelayanan Dan Varian Produk Terhadap Keputusan Pembelian pada Laboratorium Klinik Kimia Farma Bintaro. Jurnal manajemen akuntansi, 15(1). 